\title{
IGF1/insulin receptor kinase inhibition by BMS- 536924 is better tolerated than alloxan-induced hypoinsulinemia and more effective than metformin in the treatment of experimental insulin- responsive breast cancer
}

\author{
Carly Jade Dool, Haider Mashhedi, Mahvash Zakikhani, Stéphanie David, \\ Yunhua Zhao, Elena Birman, Joan M Carboni ${ }^{1}$, Marco Gottardis ${ }^{1}$, \\ Marie-José Blouin and Michael Pollak
}

\begin{abstract}
Department of Oncology, Lady Davis Research Institute of the Jewish General Hospital and Department of Oncology, McGill University, 3755 Cote-Ste-Catherine, Montreal, Quebec, Canada H3T 1E2

${ }^{1}$ Oncology Drug Discovery, Brystol-Myers Squibb Company, PO Box 5400, Princeton, New Jersey 08543, USA

(Correspondence should be addressed to M Pollak; Email: michael.pollak@mcgill.ca)
\end{abstract}

\begin{abstract}
Epidemiologic and experimental evidence suggest that a subset of breast cancer is insulin responsive, but it is unclear whether safe and effective therapies that target the insulin receptor (IR), which is homologous to oncogenes of the tyrosine kinase class, can be developed. We demonstrate that both pharmacologic inhibition of IR family tyrosine kinase activity and insulin deficiency have antineoplastic activity in a model of insulin-responsive breast cancer. Unexpectedly, in contrast to insulin deficiency, pharmacologic IR family inhibition does not lead to significant hyperglycemia and is well tolerated. We show that pharmacokinetic factors explain the tolerability of receptor inhibition relative to insulin deficiency, as the small molecule receptor kinase inhibitor BMS-536924 does not accumulate in muscle at levels sufficient to block insulin-stimulated glucose uptake. Metformin, which lowers insulin levels only in settings of hyperinsulinemia, had minimal activity in this normoinsulinemic model. These findings highlight the importance of tissue-specific drug accumulation as a determinant of efficacy and toxicity of tyrosine kinase inhibitors and suggest that therapeutic targeting of the IR family for cancer treatment is practical.
\end{abstract}

Endocrine-Related Cancer (2011) 18 699-709

\section{Introduction}

Experimental evidence that certain cancers are mitogenically responsive to insulin has been available for decades (Heuson et al. 1967) and is consistent with recent work demonstrating growth inhibitory effects of insulin receptor (IR) knockdown on neoplastic cells (Zhang et al. 2010). Clinical and epidemiologic data are consistent with these laboratory findings, as IRs are expressed in malignant tissue (Law et al. 2008, Cox et al. 2009), and higher serum levels of fasting insulin or c-peptide (a surrogate for insulin secretion) are associated with poor prognosis of common cancers (Goodwin et al. 2002, Ma et al. 2008, Wolpin et al. 2009, Pritchard et al. 2011). Further circumstantial evidence comes from a recent retrospective observation that long-term insulin administration is associated with increased cancer risk (Bowker et al. 2010), from the findings that obesity and type II diabetes (which lead to increased endogenous insulin secretion) are associated with increased cancer-specific mortality (Calle et al. 2003, Vigneri et al. 2009, Giovannucci et al. 2010) and from the demonstration that 
diet-induced (Algire et al. 2008, 2010) or transgenic (Novosyadlyy et al. 2010) models of hyperinsulinemia lead to increased IR activation and growth of experimental cancers.

Therapeutic exploitation of insulin responsiveness of cancer has traditionally been regarded as impractical because any intervention that eliminates IR activation would be predicted to lead to severe metabolic toxicity such as that seen when IRs are ablated in all organs (Kitamura et al. 2003). However, biguanides such as metformin, which are commonly used for treatment of type II diabetes, are known to be well tolerated and to decrease the elevated insulin levels present in the setting of systemic insulin resistance by a mechanism involving reduced hepatic gluconeogenesis (Shaw et al. 2005). Therefore, there is interest in the hypothesis that biguanides reduce insulin-stimulated neoplastic behavior (Pollak 2010). However, while these compounds have several potential mechanisms of action (Pollak 2010), they may not provide the most effective strategy for reducing activation of the insulin/IGF1 receptor (IGF1R) family, as they have little effect on insulin concentration if baseline levels are normal, and little effect on IGF1 levels.

The IGF1R is under clinical investigation as a molecular target for cancer therapy (Pollak 2008, Gualberto \& Pollak 2009), but IR mediated resistance to drug candidates that target the IGF1R has been described (Zhang et al. 2007, Ulanet et al. 2010). Cells that express the genes encoding both the IR and the IGF1R, such as the 4T1 mammary carcinoma cells used in our model, will display not only these receptors but also the hybrid receptors (Belfiore et al. 2009). Small molecule tyrosine kinase inhibitors designed to target IGF1R were first reported in 2004 (GarciaEcheverria et al. 2004). These also inhibit insulin and hybrid receptors and are best regarded as inhibitors of the entire insulin/IGF receptor family. There is uncertainty whether this represents a liability (because of greater risk of metabolic toxicity) or a therapeutic advantage (because of inhibition of the entire insulin/ IGF1R family) relative to highly selective anti-IGF1R antibodies that do not interact with IRs. Both specific anti-IGF1R antibodies and broader spectrum tyrosine kinase inhibitors show preclinical activity in the laboratory models (reviewed in Pollak (2008)). While IR-mediated resistance to IGF1R targeting (Zhang et al. 2007, Ulanet et al. 2010) would favor inhibition of the entire insulin/IGF1R family, there has been a widely held assumption that anti-IGF1R antibodies would be a safer strategy, considering the severity and progressive nature of metabolic abnormalities in certain IR knockout models (Kitamura et al. 2003).
BMS-536924 is one of a series of orally active small molecule tyrosine kinase inhibitors of the insulin/IGF1R family (Wittman et al. 2005). It has been found to have anticancer activity in preclinical models and to be well tolerated despite the theoretical possibility of metabolic toxicity (Litzenburger et al. 2009). A second small molecule inhibitor of the insulin and IGF1R kinase family, BMS-754807, has been shown to have an acceptable toxicity profile in the early clinical trials (Desai et al. 2010). We compared growth inhibitory activity of BMS-536924 to that of metformin and alloxan-induced hypoinsulinemia in a model of breast cancer in normoinsulinemic hosts.

Alloxan is a toxin that destroys insulin-producing pancreatic $\beta$-cells, resulting in hypoinsulinemia and hyperglycemia. It causes $\beta$-cell destruction by a mechanism involving free radical formation (Munday 1988, Munday et al. 1993, Lenzen 2008). We observed significant reductions in tumor growth following alloxan exposure or with insulin/IGF1R family kinase inhibition, but not by metformin. Alloxan led to insulin deficiency and major metabolic toxicity, but the kinase inhibitor was well tolerated, a finding we explain by demonstrating non-homogeneous drug distribution resulting in a greater deficit in muscle glucose uptake by insulin deficiency than by the kinase inhibitor.

\section{Materials and methods}

\section{Cell lines and cultures}

The 4T1 mouse breast cancer cell line characterized as a model of stage IV breast cancer was purchased from American Type Culture Collection (Manassas, VA, USA). Cells were cultured in RPM1 1640 (Wisent, St-Bruno, QC, Canada) supplemented with $10 \%$ fetal bovine serum (FBS; Invitrogen) at $37^{\circ} \mathrm{C}$.

\section{Cell proliferation assay}

The effect of insulin and IGF1 on 4T1 cells was evaluated by 3-(4,5-dimethylthiazol-2-yl)-2,5-diphenyl tetrazolium bromide (MTT; Sigma Chemical). Three thousand cells per well were plated in 96-well plates and incubated in a medium containing 10\% FBS. After $24 \mathrm{~h}$, the complete medium was replaced with serum-free medium containing different concentrations of BMS-536924 with or without $100 \mathrm{nM}$ insulin or $10 \mathrm{nM}$ IGF1 or with a medium containing various doses of insulin or IGF1 for a period of $72 \mathrm{~h}$. Proliferation assay was measured with an MTT assay as described by Blouin et al. (2010). Experiments were repeated at least twice with four replicates for each condition. 


\section{Protein extraction and western blot analysis}

Cells were washed thrice with ice-cold PBS and lysed in lysis buffer (20 mM Tris- $\mathrm{HCl}$ (pH 7.5), $150 \mathrm{mM} \mathrm{NaCl}$, $2.5 \mathrm{mM}$ sodium pyrophosphate, $1 \mathrm{mM}$ h-glycerol phosphate, $1 \mathrm{mM} \mathrm{Na} \mathrm{VO}_{4}, 1 \mathrm{mM}$ EGTA, $1 \%$ Triton, and Roche complete protease inhibitor tablet (Roche). Cell debris was removed by centrifugation. Following assay for total protein (Bio-Rad), clarified protein lysates from each experimental condition were boiled for $5 \mathrm{~min}$ and subjected to western blot analysis.

4T1 tumor and skeletal muscle were dissected from the mice at the time of killing, washed in PBS, and frozen in liquid nitrogen. The tissue samples were homogenized and sonicated in lysis buffer $(50 \mathrm{mM}$ HEPES, $1 \%$ Triton-X 100, $150 \mathrm{mM} \mathrm{NaCl}, 0.02 \%$ sodium azide, $60 \mathrm{mM} \beta$-glycerophosphate, $1 \mathrm{mM}$ dithiothreitol, protease inhibitor cocktail (complete tablets, Roche), and $5 \mu \mathrm{M}$ pepstatin $\mathrm{A}, \mathrm{pH}$ 7.2). Tissue lysates were processed in the same manner as cell lysates (above).

Proteins $(50 \mu \mathrm{g})$ were resolved electrophoretically on denaturing SDS-polyacrylamide gels (10\%), transferred to nitrocellulose membranes, and probed with the following antibodies overnight at $4{ }^{\circ} \mathrm{C}$ : antiphospho-insulin receptor (IR) ${ }^{\text {Tyr972 }} /$ IGF1R ${ }^{\text {Tyr950 }}$ (Millipore, Etobicoke, ON, Canada), anti-IR- $\alpha$, antiIR- $\beta$, anti-IGF1R, and anti- $\alpha$-tubulin (Santa-Cruz Biotechnologies, Santa Cruz, CA, USA). The position of the proteins was visualized with the appropriate HRP-conjugated anti-rabbit immunoglobulin antibody (ECL, Amersham). Experiments were repeated at least twice. Band intensity was evaluated by densitometry using Adobe Photoshop CS5 extended software, version 12.0.4 x32 (Adobe Systems Incorporated).

\section{Animals and treatment}

Female BALB/c mice aged 6 weeks were purchased from Charles River (St-Constant, QC, Canada). Animals were housed according to standard animal protocols. Alloxan exposure: forty mice aged 7 weeks were injected i.v. with $100 \mathrm{mg} / \mathrm{kg}$ of body weight of alloxan (Sigma Chemicals) dissolved in $0.85 \%$ saline. Mice treated with alloxan were given insulin injections of 1.75 IU i.p. once daily for 2 days following alloxan exposure. Their glucose level was measured 2 weeks after the injection of alloxan to determine the hyperglycemic mice. BMS-536924 treatment: at 7 weeks of age, 15 mice began oral treatment with $100 \mathrm{mg} / \mathrm{kg}$ of body weight, of BMS-536924 (kindly provided by Bristol-Myers Squibb), twice daily, starting 4 days prior to tumor cell injection so that drug distribution and early metabolic consequences would be in place. The BMS-536924 was dissolved in 4:1 concentration of polyethylene glycol 400: $\mathrm{ddH}_{2} \mathrm{O}$. Metformin treatment: $\mathrm{Balb} / \mathrm{c}$ mice received daily metformin in their drinking water at $50 \mathrm{mg} / \mathrm{kg}$ of body weight per day, as described by Algire et al. (2008). Drinking water was prepared twice weekly. This regime was started 4 days prior to tumor cell injection as for BMS-536924 treatment. 4T1 cell allograft: $10^{5} 4 \mathrm{~T} 1$ cells were injected into each flank of a) hyperglycemic mice (showing fasting blood glucose higher than $10 \mathrm{mmol} / \mathrm{l}, 2$ weeks after alloxan exposure); b) mice receiving BMS-536924; c) mice receiving metformin; and d) age-matched controls (saline i.v. injection or polyethylene glycol 400: $\mathrm{ddH}_{2} \mathrm{O}$ gavage). From day 8, tumors were measured thrice weekly and tumor volume was determined by the following formula: tumor volume $=(\pi / 6) \times($ large diameter $) \times(\text { small diameter })^{2}$. Mice were killed 4 weeks later, on which day blood samples were collected and tumors and muscle samples were dissected and frozen for future tissue studies.

\section{Metabolic assays}

Hormone serum levels were measured using rodent insulin immunoassays (Millipore) and rodent IGF1 ELISA (Diagnostic Systems Laboratories, Webster, TX, USA), according to the manufacturer's protocols.

\section{Pharmacokinetics}

\section{Preparation of tissue homogenates}

Serum and tissues (tumor, muscle, and liver) were shipped on dry ice and stored in liquid nitrogen until homogenization. Tissues were weighed and homogenized in Lysing Matrix tubes (MP Biomedicals \# 6910100, Solon, OH, USA) in distilled water (Invitrogen $\# 15230-170)$ at a ratio of 1:3 (1 part tissue, 3 parts water) for $30 \mathrm{~s}$ at room temperature using an MP Fast Prep - 24 instrument (MP Biomedicals). Serum samples and tissue homogenates were immediately analyzed as described below.

\section{Determination of BMS-536924 in serum and tissues}

Serum, muscle, liver, and tumor samples were treated with two volumes of acetonitrile containing $0.1 \mu \mathrm{g} / \mathrm{ml}$ of an appropriate internal standard. After centrifugation to remove precipitated proteins, a $6 \mu$ l portion of the resulting supernatant was analyzed by mass spectroscopy. Data acquisition was via selected reaction monitoring. Ions representing the $(\mathrm{M}+\mathrm{H})^{+}$ species for both the analyte and the IS were selected in MS1 and collisionally dissociated with argon at a pressure of $1.2 \times 10^{-3}$ Torr to form specific product 
ions that were subsequently monitored by MS2. The transition monitored for BMS-536924 was $\mathrm{m} / \mathrm{z}$ $480.1 \rightarrow 336.1$ and $m / z \quad 470.5 \rightarrow 324.3$ for the internal standard. The retention time for BMS-536924 was $0.79 \mathrm{~min}$. The four-point standard curve ranged from 5 to $5000 \mathrm{ng} / \mathrm{ml}$ and was fitted with a quadratic regression weighed by reciprocal concentration $(1 / \mathrm{x})$.

\section{Muscle glucose uptake in vivo}

Three mice from each group (control, alloxan exposed, and BMS-536924 treated) were fasted overnight and anesthetized with isoflurane $2 \%$. Prior to labeled glucose, a baseline blood sample was taken to assess fasting blood glucose and background radioactivity levels. A bolus of $1 \mathrm{mg}$ glucose containing $0.33 \mu \mathrm{Ci}$ $\left[{ }^{3} \mathrm{H}\right] 2$-deoxyglucose (2DG; Perkin Elmer, Waltham, MA, USA) per gram of mouse body weight was administered via the jugular vein. Blood samples were collected $5,10,15,25,35$, and 45 min later for plasma glucose and $\left[{ }^{3} \mathrm{H}\right]$ levels. Following the final blood collection, mice were killed and muscle samples were obtained. The tissue was immediately frozen in liquid nitrogen. Intracellular levels of $\left[{ }^{3} \mathrm{H}\right] 2 \mathrm{DG}$ were determined as described previously (Ferre et al. 1985, Witczak et al. 2006). Briefly, frozen tissue was homogenized in ice-cold buffer containing $20 \mathrm{mM}$ Tris- $\mathrm{HCl}, 5 \mathrm{mM}$ EDTA, $10 \mathrm{mM} \mathrm{Na} \mathrm{Na}_{2} \mathrm{O}_{7}$, $100 \mathrm{mM} \mathrm{NaF}, 2 \mathrm{mM} \mathrm{NaVO}_{4}, 0.01 \mathrm{mM}$ leupeptin, $3 \mathrm{mM}$ benzamidine, $1 \mathrm{mM}$ phenylmethylsulfonyl fluoride, and $10 \mu \mathrm{g} / \mathrm{ml}$ aprotinin. Muscle homogenate aliquots were placed in $\mathrm{Ba}\left(\mathrm{OH}_{2}\right) / \mathrm{ZnSO}_{4}$ and $6 \%$ perchloric acid and centrifuged. Liquid scintillation counting was used to determine the $\left[{ }^{3} \mathrm{H}\right]$ radioactivity levels in the tissue. Phosphorylated 2-deoxyglucose (2DG6P) levels were determined by the difference in supernatant radioactivity between perchloric acid and $\mathrm{Ba}\left(\mathrm{OH}_{2}\right) /$ $\mathrm{ZnSO}_{4}$-treated aliquots. Tissue glucose utilization rates were assessed by first calculating the integral of the ratio of arterial blood 2DG to plasma glucose levels. After determining the amount of 2DG6P captured by the tissue and correcting for weight, this value was divided by the integral to give an index of glucose utilization. This experiment was repeated twice.

\section{Statistical analysis}

The distribution of variables was tested for normality. A one-way or two-way ANOVA and nonparametric tests for normally and not normally distributed data were used to determine whether differences between treatment groups were significant. Additionally, the Kruskal-Wallis test was used to obtain the difference of paired value and least-squares means for multiple
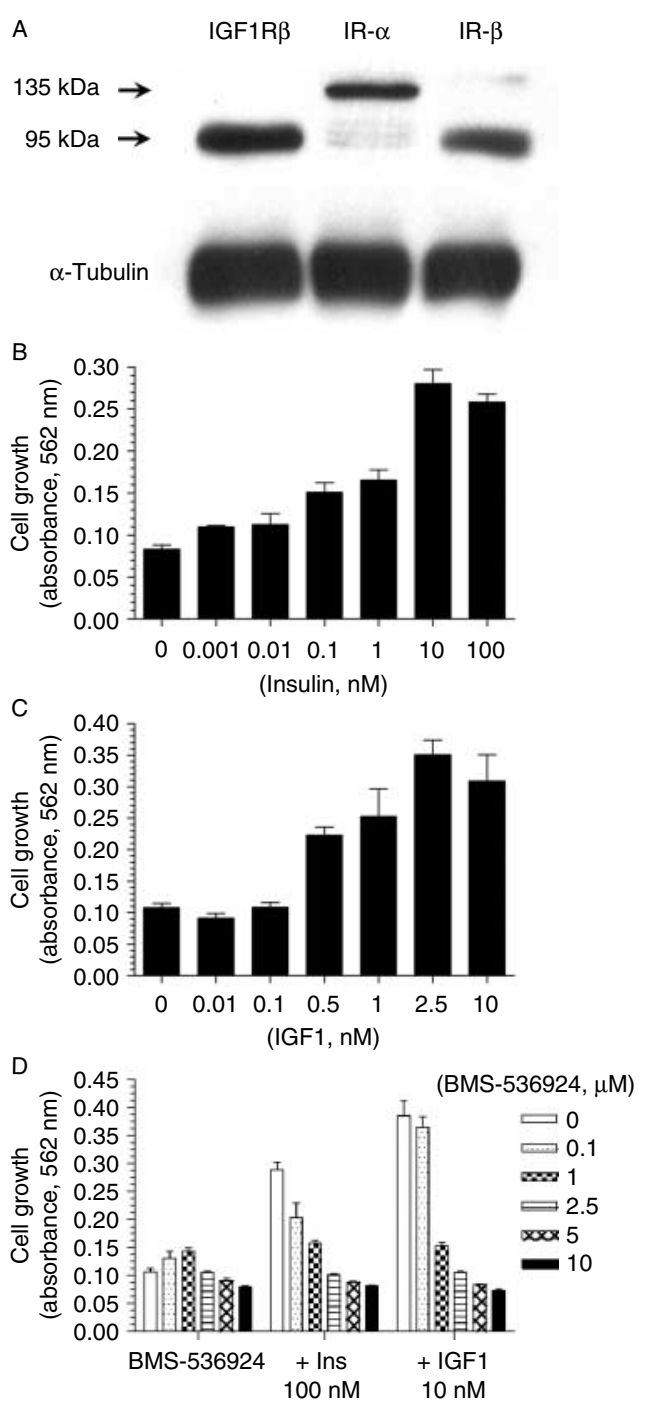

Figure 14 TT1 cells express functional insulin and IGF1 receptors. (A) $4 \mathrm{~T} 1$ cell lysates were analyzed by western blot for insulin receptor (IR) subunits $\alpha$ and $\beta$ and IGF1R $\beta$ subunit. (B-D) 4T1 cells were seeded onto 96-well plates in the presence of RPMI media with $10 \%$ FBS. After $24 \mathrm{~h}$, serum-free media containing different concentrations of insulin, IGF1, or BMS-536924 $\pm 100 \mathrm{nM}$ insulin or $10 \mathrm{nM}$ IGF1 were added. Cell proliferation in each well was measured by MTT assay after 72 h. Data represent mean \pm S.E.M. $(n=8)$. (B) Insulin stimulation of $4 \mathrm{~T} 1$ proliferation in vitro. The stimulation was statistically significant $(P=0.0023)$ compared to control from $0.1 \mathrm{nM}$ and $P<0.0001$ for higher concentrations of insulin. (C) IGF1 stimulation of 4T1 proliferation in vitro. The stimulation was statistically significant $(P=0.0113)$ compared to control from $1 \mathrm{nM}$ and $P<0.0001$ for higher concentrations of IGF1. (D) BMS-536924 inhibition of 4T1 proliferation in vitro. Inhibition by increasing concentrations of BMS-536924 was significant in the presence of $100 \mathrm{nM}$ insulin at BMS-536924 concentration from $0.1 \mu \mathrm{M}(P<0.0001)$ or in the presence of $10 \mathrm{nM}$ IGF1 at BMS-536924 concentration from $1 \mu \mathrm{M}(P<0.0001)$. 
un-pairwise comparisons of means (LSMEANS statement with Bonferroni correction). Linear mixed models (LMM) using the mixed model procedure of the SAS system was performed for tumor growth curves. All statistical analyses were performed using Statistical Analysis System software, version 9.2 (SAS Institute, Cary, NC, USA), with $P$ values $<0.05$ considered significant.

\section{Results}

\section{Insulin and IGF1R expression and insulin responsivity of $4 \mathrm{~T} 1$ mammary carcinoma cells}

4T1 murine breast cancer cells are known to form highly aggressive tumors in BALB/c mice (Aslakson \& Miller 1992, Pulaski et al. 2000, Tao et al. 2008), but they have not previously been characterized with respect to insulin or IGF1R expression. Consistent with the expression of IRs by many molecular subtypes of human breast cancer (Law et al. 2008, Belfiore et al. 2009), we observed expression of insulin and IGF1Rs by the $4 \mathrm{~T} 1$ model (Fig. 1A) and also observed in vitro mitogenic responsivity of these cells to insulin (Fig. 1B) and IGF1 (Fig. 1C) across physiologically relevant concentrations. We observed a significant inhibition of 4T1 cell proliferation with increasing doses of BMS-536924 in the presence of insulin or IGF1 (Fig. 1D), but not in ligand-free and serum-free medium, consistent with its published mechanism of action on the insulin/IGF receptor family.

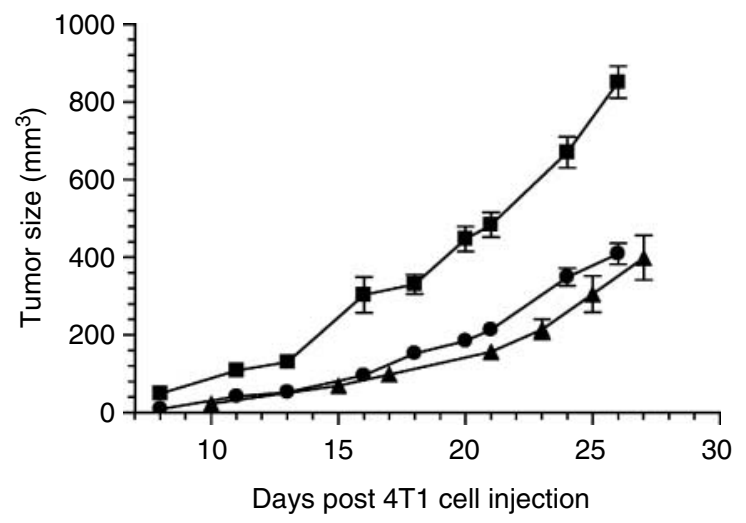

Figure 2 Alloxan-induced hypoinsulinemia and BMS-536924 lead to decreased 4T1 tumor proliferation. Alloxan-treated mice (closed triangles) and mice treated with BMS-536924 (closed circles) displayed a significant reduction of $4 \mathrm{~T} 1$ tumor growth in the BALB/c mouse model compared with control (closed squares). Data represent the mean \pm S.E.M. The difference was highly significant between control and alloxan or BMS-536924 $(P<0.0001)$.
Table 1 Condition of mice at the conclusion of the experiment

\begin{tabular}{|c|c|c|}
\hline & $\begin{array}{l}\text { Percentage of mice } \\
\text { meeting animal care } \\
\text { criteria for killing } \\
\text { due to tumor size by } \\
\text { day } 27 \text { following } \\
\text { tumor cell injection }\end{array}$ & $\begin{array}{l}\text { Percentage of mice } \\
\text { with signs of meta- } \\
\text { bolic toxicity with } \\
27 \text { days of tumor } \\
\text { cell injection }\end{array}$ \\
\hline Control $(n=28)$ & 71 & 0 \\
\hline $\begin{array}{l}\text { Alloxan } \\
\quad \text { exposed } \\
(n=18)\end{array}$ & 0 & 61 \\
\hline $\begin{array}{l}\text { BMS-536924 } \\
\text { treated } \\
(n=15)\end{array}$ & 0 & 0 \\
\hline $\begin{array}{l}\text { Metformin trea- } \\
\text { ted }(n=10)\end{array}$ & 67 & 0 \\
\hline
\end{tabular}

\section{Both BMS-536924 and alloxan-induced insulin deficiency inhibit 4T1 tumor growth in vivo}

$10^{5} 4 \mathrm{~T} 1$ cells were injected s.c. in flanks of control mice, mice rendered insulin deficient by a single injection of $100 \mathrm{mg} / \mathrm{kg}$ of body weight of alloxan 2 weeks prior, or mice that received BMS-536924 orally at a dose of $100 \mathrm{mg} / \mathrm{kg}$ twice daily. Tumors in control mice were palpable within a week and measurable by calipers at day 8 (Fig. 2). Prior alloxan exposure or BMS-536924 treatment, each led to easily observable and statistically significant $(P<0.0001$ in each case) reductions in tumor growth relative to control (mean tumor size at the end of the experiment \pm (s.E.M.): alloxan: $399 \pm 57 \mathrm{~mm}^{3}$, BMS-536924: $409 \pm 27 \mathrm{~mm}^{3}$, control: $852 \pm 41 \mathrm{~mm}^{3}$ ). As shown in Table 1, tumor growth reached criteria for animal welfare guideline for killing by day 27 in $71 \%$ of untreated animals, but in none of the animals with alloxan-induced insulin deficiency, and in none of the animals on BMS-536924.

\section{Metabolic effects of interventions}

As expected, alloxan exposure led to insulin deficiency and severe hyperglycemia, attributable to its toxic effects on pancreatic $\beta$-cells. In contrast, BMS-536924 treatment led to hyperinsulinemia but minor hyperglycemia (Table 2). The perturbations of insulin and glucose levels following administration of BMS536924 represent pharmacodynamic evidence that the drug is active in reducing IR activation, leading to compensatory hyperinsulinemia. While BMS-536924 is known to inhibit both insulin and IGF1R signaling, the effect of alloxan on pancreatic $\beta$-cells would be expected to preferentially reduce circulating levels of 
Table 2 Effects of alloxan, BMS-536924, and metformin on insulin, IGF1, glucose, and body weight

\begin{tabular}{lcccc}
\hline & Control & $\begin{array}{c}\text { Alloxan }(2 \text { weeks after single } \\
\text { dose of } 100 \mathrm{mg} / \mathrm{kg} \text { i.v. })\end{array}$ & $\begin{array}{c}\text { BMS-536924 (100 mg/kg } \\
\text { p.o., twice daily) }\end{array}$ & $\begin{array}{c}\text { Metformin (50 mg/kg in } \\
\text { drinking water) }\end{array}$ \\
\hline Insulin $(\mathrm{ng} / \mathrm{ml})^{\mathrm{a}}$ & $0.34 \pm 0.06$ & $0.038 \pm 0.060$ & $14.38 \pm 2.95$ & $0.28 \pm 0.02$ \\
IGF1 $(\mathrm{ng} / \mathrm{ml})^{\mathrm{a}}$ & $598.31 \pm 30.58$ & $253.82 \pm 43.84$ & $680.95 \pm 28.37$ & $725.08 \pm 44.53$ \\
Glucose $(\mathrm{mmol} / \mathrm{l})$ & $4.24 \pm 0.12$ & $21.54 \pm 0.92$ & $5.40 \pm 0.19$ & $6.44 \pm 0.22$ \\
Body weight $(\mathrm{g})^{\mathrm{a}}$ & $19.31 \pm 0.18$ & $16.88 \pm 0.66$ & $19.37 \pm 0.23$ & $18.38 \pm 0.17$ \\
\hline
\end{tabular}

Insulin levels were significantly different between control and BMS-536924 groups $(P<0.0001)$ and also between alloxan and BMS-536924 groups $(P<0.0001)$. IGF1 levels were significantly different $(P<0.0001)$ between alloxan and control, BMS-536924, or metformin groups. Glucose levels were significantly different between control and alloxan groups $(P<0.0001)$, between alloxan and BMS-536924 groups $(P<0.0001)$, between alloxan and metformin groups $(P<0.0001)$, and also between control and BMS-536924 groups $(P=0.0135)$. Finally, body weight was significantly different between control and alloxan groups $(P=0.0002)$, and between alloxan and BMS-536924 groups $(P=0.0027)$. There were no significant differences between control and metformin-treated mice. ablood was sampled prior to killing from mice with free access to food and water.

insulin, as observed. A reduction of IGF1 levels was also observed following alloxan exposure, in keeping with a report (Glaser et al. 1987) showing suppressed IGF1 levels as a consequence of uncontrolled diabetes.

Many alloxan-exposed mice showed signs of poorly controlled type I diabetes such as dehydration and weight loss (mean body weight grams \pm s.E.M.: $16.88 \pm$ 0.66 vs $19.37 \pm 0.23$ for alloxan vs control respectively; Table 2). Data in Table 1 show that the majority of alloxan-exposed mice were obviously ill with uncontrolled diabetes by day 27 following tumor cell injections, while BMS-536924-treated and control animals appeared normal.

\section{Investigation of differences in toxicity between insulin deficiency and insulin/IGF1R kinase inhibition}

In order to determine whether drug distribution could be related to differences in toxicity, we measured drug levels in muscle, tumors, and serum (Fig. 3A). The concentration of BMS-536924 (means \pm s.E.M.) in muscle was $7.785 \pm 4.475 \mu \mathrm{M}$, compared to $48.190 \pm$ $5.092 \mu \mathrm{M}$ in neoplastic tissue $(P=0.0055)$, and $735.458 \pm 81.638 \mu \mathrm{M}$ in serum $(P<0.0001$ serum vs muscle and tumor). This raised the possibility that IR inhibition and insulin-stimulated glucose uptake by muscle would be more completely inhibited by insulin deficiency than by exposure to BMS-536924.

Figure 3B shows that alloxan-induced insulin deficiency was associated with reduced IR activation in muscle. Alloxan-induced hypoinsulinemia was also associated with reduced IR activation in neoplastic tissue, indicating an effect of the host metabolic derangements on signal transduction within neoplastic cells. IR phosphorylation in neoplastic tissue of animals treated with BMS-536924 was reduced to $\sim 55 \%$ of control levels, an effect compared to that of alloxan-induced insulin deficiency. However, in muscle, there was no significant difference in IR phosphorylation between control and BMS-536924treated animals. BMS-536924 treatment or alloxan exposure did not affect the levels of total insulin and IGF1R receptors. This suggests that the observed variation in BMS-536924 accumulation in different tissues results in tissue-specific variation in degree of receptor inhibition, with less inhibition in muscle than neoplastic tissue.

In vivo glucose utilization was measured in order to evaluate muscle glucose uptake in mice undergoing BMS-536924 treatment. In keeping with the observation that insulin deficiency resulted in hyperglycemia while BMS-536924 administration did not, glucose uptake by muscle was decreased in the alloxan-exposed group, but increased in the BMS536924-treated animals (Fig. 4). This increase is compatible with the hyperinsulinemia associated with BMS-536924 administration and the relatively low accumulation of the compound in muscle compared with neoplastic tissue.

Figure 5 shows in vivo growth of 4T1 tumors in mice treated with metformin (in drinking water as described in Materials and methods section) or not. Metformin had no significant growth inhibitory activity or insulinlowering activity in this normoinsulinemic model, in contrast to its demonstrated activity in other models where hosts are hyperinsulinemic (Algire et al. 2008). The hormone levels of mice treated with metformin were not significantly different than for control animals (Table 2). Thus, our results show that three interventions relevant to the insulin/IGF1R family have different impacts on the 4T1 model. The insulin/ IGF1R kinase inhibitor reduces tumor growth and is relatively well tolerated; prior exposure to alloxan also inhibits tumor growth and is associated with reduced concentration of insulin and IGF1 levels and hyperglycemia, and metformin has no tumor growth inhibitory effect and no effect on ligand levels. 


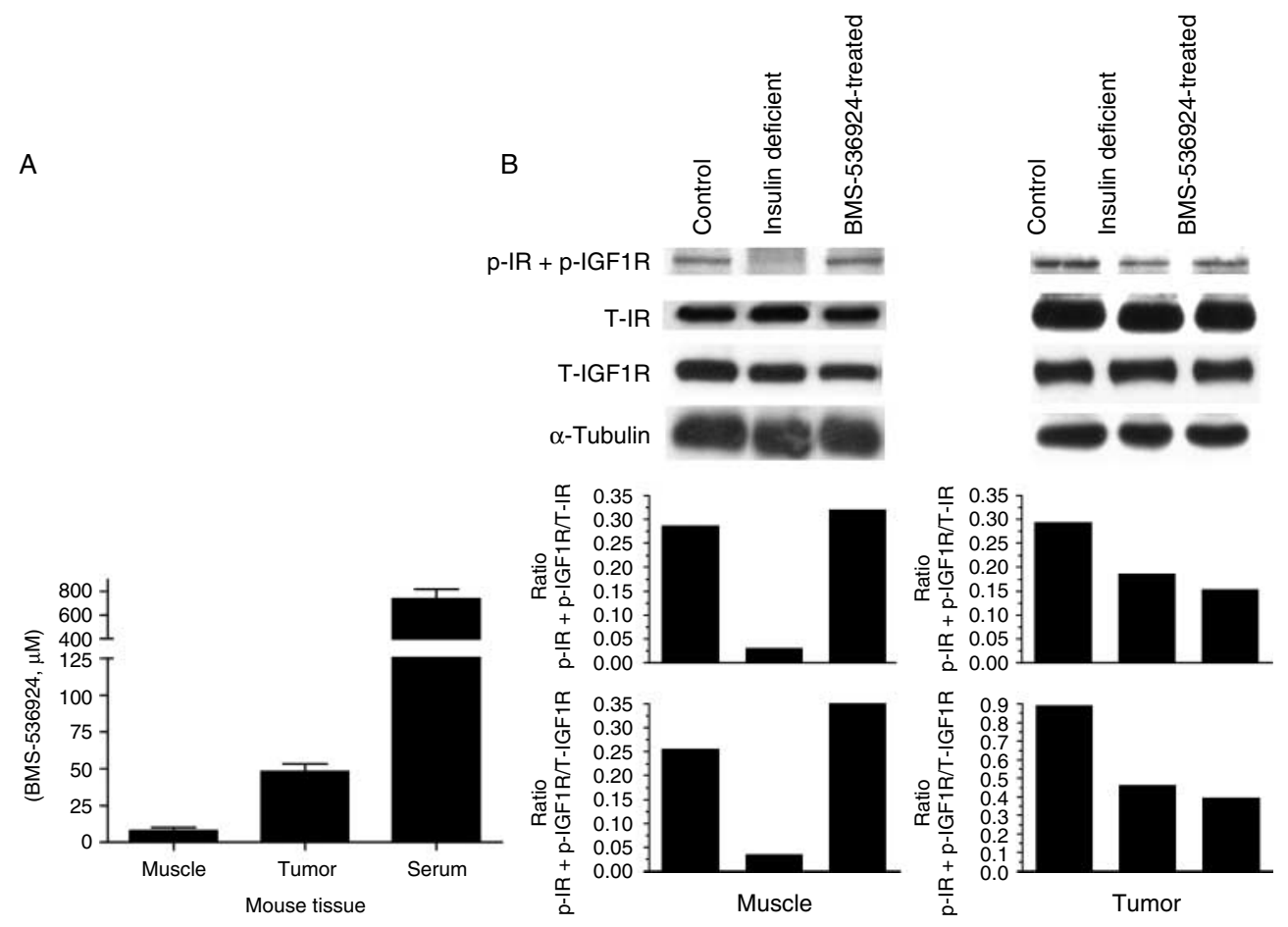

Figure 3 (A) BMS-536924 tissue distribution. $200 \mathrm{~mm}^{3}$ samples of skeletal muscle, 4T1 tumor, and $200 \mu \mathrm{l}$ serum were collected from mice at the time of killing. BMS-536924 drug levels were measured as described in the Materials and methods section. Data represent the mean \pm S.E.M. among the tissues $(P<0.0001)$. (B) Both insulin deficiency and BMS-536924 treatment result in decreased insulin receptor activation in neoplastic tissue but have different effects in skeletal muscle. 4T1 tumor and muscle from control, alloxan-exposed, and BMS-536924-treated mice were analyzed by western blot analysis for phospho-IR ${ }^{\text {Tyr972 }}$, IGF1R ${ }^{\text {Tyr950 }}$, IR and IGF1R, and $\alpha$-tubulin. Data shown are representative of three independent experiments.

\section{Discussion}

The observation that insulin stimulates in vitro proliferation and insulin deficiency reduces in vivo growth of 4T1 mammary cancer supports the hypothesis that certain cancers grow in an insulin-responsive manner. This is biologically plausible, as IRs are expressed by the 4T1 cells used in our model and also by human cancers. IRs are homologous to oncogenes of the tyrosine kinase class (Ullrich et al. 1985) and activate pathways known to favor cellular proliferation and survival (Pollak et al. 2004, Pollak 2008). Indeed, in an evolutionary context, regulation of cell survival and growth by insulin-like signaling predated the relatively recent specialized functions of insulin as a regulator of blood glucose levels. It is likely that effects of variation in caloric intake on tumor growth are attributable at least in part to changes in insulin levels (Kalaany \& Sabatini 2009, Pollak 2009). Insulin stimulation of neoplastic growth is not predicted to be universal: for example, cancers with activating mutations of PI3 kinase or other signaling molecules downstream of the IR would be expected to proliferate aggressively in an insulin-independent manner.
As expected, alloxan-induced insulin deficiency is shown to be associated with metabolic derangements typical of type I diabetes that make it impractical as an approach to treatment of insulin-dependent cancers, but it is of interest that in this experimental system tumor growth was inhibited. This contrasts with type II

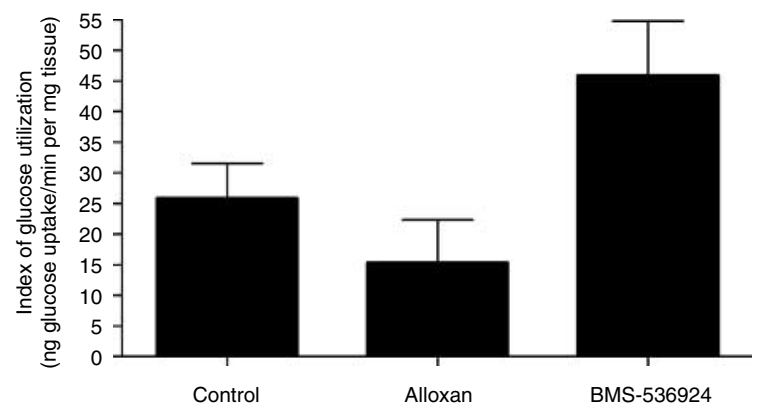

Figure 4 Glucose uptake in muscle decreases following alloxan exposure but increases with BMS-536924 treatment. Mice were given an i.v. injection of a $1 \mathrm{mg}$ glucose $/ \mathrm{g}$ of body weight bolus containing $\left[{ }^{3} \mathrm{H}\right] 2$-deoxyglucose. Mice were untreated, exposed to alloxan 2 weeks previously, or on treatment with BMS-53924 that had been started 4 days prior. Glucose uptake in muscle was determined as described in the Materials and methods section. Data represent the mean \pm S.E.M. $(P=0.0635, n=6)$. 


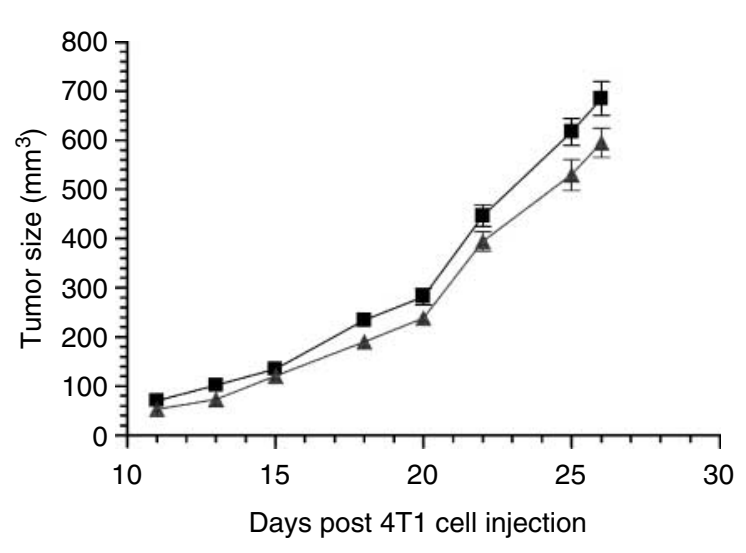

Figure 5 Metformin treatment does not decrease 4T1 tumor growth. Metformin-treated mice (closed triangles) do not display a significant reduction of $4 \mathrm{~T} 1$ tumor growth in the BALB/C mouse model compared with control (closed squares). Data represent the mean \pm S.E.M. $(P=0.4133, n=10)$.

diabetes and/or diet-induced obesity models, where the metabolic derangements include hyperinsulinemia and are associated with accelerated tumor growth (Algire et al. 2008, 2010, 2011). BMS-536924 is as effective as insulin deficiency in constraining cancer growth, but is well tolerated relative not only to insulin deficiency but also to systemic IR knockdown (Kitamura et al. 2003). This somewhat unexpected safety can be explained by our findings. Muscle glucose uptake is reduced by insulin deficiency in our model, leading to hyperglycemia, but little changed by BMS-536924, an observation in keeping with the relatively low accumulation of the drug in muscle tissue.

The literature on IR knockout mice (reviewed in Fernandez et al. (2001) and Kitamura et al. (2003)) demonstrates complexities in the tissue-specific role of IRs in glucose homeostasis and other functions. Our data suggest that superimposed upon this complexity, heterogeneity of drug distribution of small molecule kinase inhibitors that target the IR family results in a degree of kinase inhibition, which varies in a tissuespecific manner. In our model, this leads to inhibition of neoplastic growth, but relatively mild metabolic derangement. In particular, insulin action in muscle, which is a major site for insulin-mediated glucose uptake, is shown to be preserved during BMS-536924 treatment, an observation that is plausible in the context of the relatively low accumulation of the kinase inhibitor in this tissue, and the inhibitor-induced systemic hyperinsulinemia. The precise mechanism underlying the relatively low drug levels in muscle is under investigation.

Metformin is a widely used glucose-lowering and insulin-lowering agent with recently described antineoplastic activity in certain experimental models. This activity has been attributed to several mechanisms, one of which is reduction in the elevated insulin levels (Pollak 2010) typical of obesity and early type II diabetes. There is experimental evidence that reduction of insulin levels by metformin, which is secondary to reduction of hepatic glucose output (Shaw et al. 2005), is only significant in the setting of baseline hyperinsulinemia (Algire et al. 2008, 2010). Although there is epidemiologic evidence for decreased cancer burden associated with metformin use (Vigneri et al. 2009, Giovannucci et al. 2010), these data were derived from type II diabetics, who are in general hyperinsulinemic, so extrapolation to the general population is not possible. Thus, metformin and similar compounds may not be optimal for targeting insulinstimulated tumor growth, especially in normoinsulinemic patients. Our data provide an example of a tumor for which normal levels of ligands for the insulin/IGF1R family are sufficient to stimulate growth and demonstrate that under these conditions BMS-536924 is active, but metformin (at doses active in hyperinsulinemic models) is not. Thus, lack of effect of metformin on tumor growth should not be taken as evidence that the insulin/IGF1R family is without influence. However, there may be situations where actions of metformin other than reduction of insulin level are important (Zakikhani et al. 2006, 2010, Ning \& Clemmons 2010, Algire et al. 2011).

Our observations provide evidence contrary to the view that insulin acts to constrain cancer growth by reducing glucose level, which has been hypothesized to limit neoplastic growth by reducing the high level of glycolysis common to transformed cells (Gerstein 2010, Johnson \& Pollak 2010). This hypothesis predicts that the hyperglycemia seen in the setting of hypoinsulinemia would accelerate tumor growth, but the opposite was observed, suggesting that at least for some cancers IR activation has a more important effect on tumor growth than variations in glucose levels in the range of 5-20 mM. The lack of a stimulatory influence of hyperglycemia on neoplastic growth, despite the high glucose requirements needed for energy generation by glycolysis, is likely due to the fact that many tumors have constitutively active and high rates of glucose uptake and can easily satisfy their glucose requirements even under normoglycemic conditions.

Technical constraints precluded expansion of this study to human xenografts, transgenic tumor models, or chemical carcinogenesis models, because severe insulin deficiency is poorly tolerated by immunodeficient mice, and because of the need to accurately measure tumor growth in a time window where 
hypoinsulinemia is present, but severe metabolic toxicity has not yet developed. It is unlikely that alloxan directly affected tumor biology, as alloxan was injected several weeks prior to tumor cells. Many endocrine changes are associated with alloxan-induced insulin deficiency, but our signaling data is compatible with the view that insulin reduction itself plays a key role in the effects of alloxan.

Our model provides an example of a mammary tumor that is inhibited by insulin deficiency or the insulin/IGF1R family kinase inhibitor BMS-536924 (but not metformin) and provides an explanation for the lack of toxicity of the kinase inhibitor relative to insulin deficiency. IR expression is common in human breast cancer (Law et al. 2008), but further clinical research is required to determine the proportion of IR expressing tumors that are sensitive to IR targeting strategies.

\section{Declaration of interest}

Dr Carboni and Dr Gottardis are employed by Brystol-Myers Squibb Company. Ms Dool, Mr Mashhedi, Dr Zakikhani, Mrs David, Dr Zhao, Dr Birman, Dr Blouin, and Dr Pollak declare no potential conflict of interest.

\section{Funding}

This work was supported by grants from the Terry Fox Research Institute and Canadian Cancer Society Research Institute. Ms Dool is supported through the Montreal Centre for Experimental Therapeutics in Cancer Strategic Training Program. Mr Mashhedi is supported through the McGill Integrated Cancer Research Training Program.

\section{Acknowledgements}

We thank Lorell Discenza (Brystol-Myers Squibb) for homogenization of tissues and determination of BMS536924 drug levels and Michael Hirshman (Joslin Diabetes Center, Harvard Medical School, Boston, Massachusetts) and Fernando Escrivà (Facultad de Farmacia, Universidad Complutense, Madrid, Spain) for their assistance with the in vivo glucose uptake technique.

\section{References}

Algire C, Zakikhani M, Blouin M-J, Shuai JH \& Pollak M 2008 Metformin attenuates the stimulatory effect of a high energy diet on in vivo H59 carcinoma growth. EndocrineRelated Cancer 15 833-839. (doi:10.1677/ERC-08-0038)

Algire C, Amrein L, Zakikhani M, Panasci L \& Pollak M 2010 Metformin blocks the stimulative effect of a high energy diet on colon carcinoma growth in vivo and is associated with reduced expression of fatty acid acid synthase. Endocrine-Related Cancer 17 351-360. (doi:10.1677/ERC-09-0252)

Algire C, Amrein L, Bazile M, David S, Zakikhani M \& Pollak M 2011 Diet and tumor LKB1 expression interact to determine sensitivity to anti-neoplastic effects of metformin in vivo. Oncogene 30 1174-1182. (doi:10. 1038/onc.2010.483)

Aslakson CJ \& Miller FR 1992 Selective events in the metastatic process defined by analysis of the sequential dissemination of subpopulations of a mouse mammary tumor. Cancer Research 52 1399-1405.

Belfiore A, Frasca F, Pandini G, Sciacca L \& Vigneri R 2009 Insulin receptor isoforms and insulin receptor/insulin-like growth factor receptor hybrids in physiology and disease. Endocrine Reviews 30 586-623. (doi:10.1210/er.2008-0047)

Blouin MJ, Zhao Y, Zakikhani M, Algire C, Piura E \& Pollak M 2010 Loss of function of PTEN alters the relationship between glucose concentration and cell proliferation, increases glycolysis, and sensitizes cells to 2-deoxyglucose. Cancer Letters 289 246-253. (doi:10. 1016/j.canlet.2009.08.021)

Bowker SL, Yasui Y, Veugelers P \& Johnson JA 2010 Glucose-lowering agents and cancer mortality rates in type 2 diabetes: assessing effects of time-varying exposure. Diabetologia 53 1631-1637. (doi:10.1007/ s00125-010-1750-8)

Calle EE, Rodriguez C, Walker-Thurmond K \& Thun MJ 2003 Overweight, obesity, and mortality from cancer in a prospectively studied cohort of U.S. adults. New England Journal of Medicine 348 1625-1638. (doi:10.1056/ NEJMoa021423)

Cox M, Gleave M, Zakikhani M, Bell R, Piura E, Vickers E, Cunningham M, Larsson O, Fazli L \& Pollak M 2009 Insulin receptor expression by human prostate cancers. Prostate 69 33-40. (doi:10.1002/pros.20852)

Desai J, Solomon BJ, Davis ID, Lipton LR, Hicks R, Scott AM, Park J, Clemens PL, Gestone TA \& Finckenstein FG 2010 Phase I dose-escalation study of daily BMS-754807, an oral, dual IGF-1R/insulin receptor (IR) inhibitor in subjects with solid tumors. Proceedings of ASCO. Journal of Clinical Oncology 28 (Suppl) abstr 3104.

Fernandez AM, Kim JK, Yakar S, Dupont J, HernandezSanchez C, Castle AL, Filmore J, Shulman GI \& Le Roith D 2001 Functional inactivation of the IGF-I and insulin receptors in skeletal muscle causes type 2 diabetes. Genes and Development 15 1926-1934. (doi:10.1101/gad.908001)

Ferre P, Leturque A, Burnol AF, Penicaud L \& Girard J 1985 A method to quantify glucose utilization in vivo in skeletal muscle and white adipose tissue of the anaesthetized rat. Biochemical Journal 228 103-110.

Garcia-Echeverria C, Pearson MA, Marti A, Meyer T, Mestan J, Zimmermann J, Gao J, Brueggen J, Capraro H-G, Cozens R et al. 2004 In vivo anti-tumor activity of NVP-AEW541 - a novel, potent and selective inhibitor of the IGF-IR kinase. Cancer Cell 5 231-239. (doi:10.1016/S1535-6108(04)00051-0) 
Gerstein HC 2010 Does insulin therapy promote, reduce, or have a neutral effect on cancers? Journal of the American Medical Association 303 446-447. (doi:10.1001/jama. 2010.60)

Giovannucci E, Harlan DM, Archer MC, Bergenstal RM, Gapstur SM, Habel LA, Pollak M, Regensteiner JG \& Yee D 2010 Diabetes and cancer - a consensus report. Diabetes Care 33 1674-1685. (doi:10.2337/dc10-0666)

Glaser EW, Goldstein S \& Phillips LS 1987 Nutrition and somatomedin. XVII. Circulating somatomedin C during treatment of diabetic ketoacidosis. Diabetes 36 1152-1160. (doi:10.2337/diabetes.36.10.1152)

Goodwin PJ, Ennis M, Pritchard KI, Trudeau ME, Koo J, Madarnas Y, Hartwick W, Hoffman B \& Hood N 2002 Fasting insulin and outcome in early-stage breast cancer: results of a prospective cohort study. Journal of Clinical Oncology 20 42-51. (doi:10.1200/JCO.20.1.42)

Gualberto A \& Pollak M 2009 Emerging role of insulin-like growth factor receptor inhibitors in oncology: early clinical trial results and future directions. Oncogene 28 3009-3021. (doi:10.1038/onc.2009.172)

Heuson JC, Coune A \& Heimann R 1967 Cell proliferation induced by insulin in organ culture of rat mammary carcinoma. Experimental Cell Research 45 351-360. (doi:10.1016/0014-4827(67)90185-1)

Johnson JA \& Pollak M 2010 Insulin, glucose and the increased risk of cancer in patients with type 2 diabetes. Diabetologia 53 2086-2088. (doi:10.1007/s00125-0101855-0)

Kalaany NY \& Sabatini DM 2009 Tumours with PI3K activation are resistant to dietary restriction. Nature $\mathbf{4 5 8}$ 725-731. (doi:10.1038/nature07782)

Kitamura T, Kahn CR \& Accili D 2003 Insulin receptor knockout mice. Annual Review of Physiology $\mathbf{6 5}$ 313-332. (doi:10.1146/annurev.physiol.65.092101. 142540)

Law JH, Habibi G, Hu K, Masoudi H, Wang MYC, Stratford AL, Park E, Gee JMW, Finlay P, Jones HE et al. 2008 Phosphorylated insulin-like growth factor-1/insulin receptor is present in all breast cancer subtypes and is related to poor survival. Cancer Research 68 10238-10246. (doi:10.1158/0008-5472.CAN-08-2755)

Lenzen S 2008 The mechanisms of alloxan- and streptozotocin-induced diabetes. Diabetologia $\mathbf{5 1}$ 216-226. (doi:10.1007/s00125-007-0886-7)

Litzenburger BC, Kim HJ, Kuiatse I, Carboni JM, Attar RM, Gottardis MM, Fairchild CR \& Lee AV 2009 BMS536924 reverses IGF-IR-induced transformation of mammary epithelial cells and causes growth inhibition and polarization of MCF7 cells. Clinical Cancer Research 15 226-237. (doi:10.1158/1078-0432.CCR-08-0801)

Ma J, Li H, Giovannucci E, Mucci L, Qiu W, Nguyen P, Gaziano JM, Pollak M \& Stampfer M 2008 Prediagnostic body-mass index, plasma C-peptide concentration, and prostate cancer-specific mortality in men with prostate cancer: a long-term survival analysis. Lancet Oncology 9 1039-1047. (doi:10.1016/S1470-2045(08)70235-3)
Munday R 1988 Dialuric acid autoxidation. Effects of transition metals on the reaction rate and on the generation of "active oxygen" species. Biochemical Pharmacology 37 409-413. (doi:10.1016/0006-2952(88)90207-9)

Munday R, Ludwig K \& Lenzen S 1993 The relationship between the physicochemical properties and the biological effects of alloxan and several $\mathrm{N}$-alkyl substituted alloxan derivatives. Journal of Endocrinology 139 153-163. (doi:10.1677/joe.0.1390153)

Ning J \& Clemmons DR 2010 AMP-activated protein kinase inhibits IGF-I signaling and protein synthesis in vascular smooth muscle cells via stimulation of insulin receptor substrate $1 \mathrm{~S} 794$ and Tuberous sclerosis $2 \mathrm{~S} 1345$ phosphorylation. Molecular Endocrinology $\mathbf{2 4}$ 1218-1229. (doi:10.1210/me.2009-0474)

Novosyadlyy R, Lann DE, Vijayakumar A, Rowzee A, Lazzarino DA, Fierz Y, Carboni JM, Gottardis MM, Pennisi PA, Molinolo AA et al. 2010 Insulin-mediated acceleration of breast cancer development and progression in a nonobese model of type 2 diabetes. Cancer Research 70 741-751. (doi:10.1158/0008-5472. CAN-09-2141)

Pollak M 2008 Insulin and insulin-like growth factor signalling in neoplasia. Nature Reviews. Cancer $\mathbf{8}$ 915-928. (doi:10.1038/nrc2536)

Pollak M 2009 Do cancer cells care if their host is hungry? Cell Metabolism 9 401-403. (doi:10.1016/j.cmet.2009. 04.006)

Pollak M 2010 Metformin and other biguanides in oncology: advancing the research agenda. Cancer Prevention Research 3 1060-1065. (doi:10.1158/1940-6207.CAPR10-0175)

Pollak MN, Schernhammer ES \& Hankinson SE 2004 Insulin-like growth factors and neoplasia. Nature Reviews. Cancer 4 505-518. (doi:10.1038/nrc1387)

Pritchard KI, Shepherd LE, Chapman JW, Norris BD, Cantin J, Goss PE, Dent SF, Walde D, Vanderberg TA, Findlay B et al. 2011 Randomized trial of tamoxifen versus combined tamoxifen and octreotide LAR therapy in the adjuvant treatment of early-stage breast cancer in postmenopausal women: NCIC CTG MA. Journal of Clinical Oncology [in press]. (doi:10.1200/JCO.2010.33.7006)

Pulaski BA, Terman DS, Khan S, Muller E \& OstrandRosenberg S 2000 Cooperativity of Staphylococcal aureus enterotoxin B superantigen, major histocompatibility complex class II, and CD80 for immunotherapy of advanced spontaneous metastases in a clinically relevant postoperative mouse breast cancer model. Cancer Research 60 2710-2715.

Shaw RJ, Lamia KA, Vasquez D, Koo SH, Bardeesy N, Depinho RA, Montminy M \& Cantley LC 2005 The kinase LKB1 mediates glucose homeostasis in liver and therapeutic effects of metformin. Science 310 1642-1646. (doi:10.1126/science.1120781)

Tao K, Fang M, Alroy J \& Sahagian GG 2008 Imagable 4T1 model for the study of late stage breast cancer. $B M C$ Cancer 8 228. (doi:10.1186/1471-2407-8-228) 
Ulanet DB, Ludwig DL, Kahn CR \& Hanahan D 2010 Insulin receptor functionally enhances multistage tumor progression and conveys intrinsic resistance to IGF-1R targeted therapy. PNAS 107 10791-10798. (doi:10.1073/ pnas.0914076107)

Ullrich A, Bell JR, Chen EY, Herrera R, Petruzzelli LM, Dull TJ, Gray A, Coussens L, Liao YC \& Tsubokawa M 1985 Human insulin receptor and its relationship to the tyrosine kinase family of oncogenes. Nature $\mathbf{3 1 3}$ 756-761. (doi:10.1038/313756a0)

Vigneri P, Frasca F, Sciacca L, Pandini G \& Vigneri R 2009 Diabetes and cancer. Endocrine-Related Cancer 16 1103-1123. (doi:10.1677/ERC-09-0087)

Witczak CA, Hirshman MF, Jessen N, Fujii N, Seifert MM, Brandauer J, Hotamisligil GS \& Goodyear LJ 2006 JNK1 deficiency does not enhance muscle glucose metabolism in lean mice. Biochemical and Biophysical Research Communications 350 1063-1068. (doi:10.1016/j.bbrc. 2006.09.158)

Wittman M, Carboni J, Attar R, Balasubramanian B, Balimane P, Brassil P, Beaulieu F, Chang C, Clarke W, Dell J et al. 2005 Discovery of a (1H-benzoimidazol-2yl)-1H-pyridin-2-one (BMS-536924) inhibitor of insulinlike growth factor I receptor kinase with in vivo antitumor activity. Journal of Medicinal Chemistry 48 5639-5643. (doi:10.1021/jm050392q)

Wolpin BM, Meyerhardt JA, Chan AT, Ng K, Chan JA, Wu K, Pollak MN, Giovannucci EL \& Fuchs CS 2009 Insulin, the insulin-like growth factor axis, and mortality in patients with nonmetastatic colorectal cancer. Journal of Clinical Oncology 27 176-185. (doi:10.1200/ JCO.2008.17.9945)

Zakikhani M, Dowling R, Fantus IG, Sonenberg N \& Pollak M 2006 Metformin is an AMP kinase-dependent growth inhibitor for breast cancer cells. Cancer Research 66 10269-10273. (doi:10.1158/0008-5472.CAN-061500)

Zakikhani M, Blouin M-J, Piura E \& Pollak M 2010 Metformin and rapamycin have distinct effects on the AKT pathway and proliferation in breast cancer cells. Breast Cancer Research and Treatment 123 271-279. (doi:10.1007/s10549-010-0763-9)

Zhang H, Pelzer AM, Kiang DT \& Yee D 2007 Downregulation of type I insulin-like growth factor receptor increases sensitivity of breast cancer cells to insulin. Cancer Research 67 391-397. (doi:10.1158/0008-5472. CAN-06-1712)

Zhang H, Fagan DH, Zeng X, Freeman KT, Sachdev D \& Yee D 2010 Inhibition of cancer cell proliferation and metastasis by insulin receptor downregulation. Oncogene 29 2517-2527. (doi:10.1038/onc.2010.17)

Received in final form 13 September 2011

Accepted 22 September 2011

Made available online as an Accepted Preprint 26 September 2011 